\title{
Development of a Real-time RT-PCR Method for Rapid Detection and Quantification of Southern Rice Black-streaked Dwarf Virus in Rice
}

\author{
Songbai Zhang ${ }^{1}$, Deyong Zhang ${ }^{1,2 *}$, Yong Liu ${ }^{1,2}$, Xiangwen Luo ${ }^{1}$, Jue Cheng ${ }^{1}$ and Jing Peng ${ }^{1}$
}

${ }^{1}$ Hunan Plant Protection Institute, Hunan Academy of Agricultural Science, Changsha 410125, China

${ }^{2}$ Longping Branch, Graduate College, Central South University, Changsha 410125, China

\begin{abstract}
Southern Rice Black-Streaked Dwarf Virus (SRBSDV) was a new pathogen species in genus Fijivirus group 2 , which caused serious yield loss of many important cereal crops, such as rice and maize, in the past four years (2008-2011), which are imported in China and Southeast Asia. Notably, there are no typical symptoms in early infected rice, which can prevent serious yield loss. So, it is very important for detection of the early stage of infection of SRBSDV in rice. To this end, a real-time RT-PCR method was established and used to detect this virus in rice samples, and it was also compared with the conventional RT-PCR. The result showed that the real-time RT-PCR possessed high specificity and sensitivity for SRBSDV detecting, and the relationship between Ct values and copy number of SRBSDV was linear with a range of $4.04 \times 10^{2}-4.04 \times 10^{7}$ copies/reaction, and the sensitivity reached 150 copies/reaction. The intra- and inter-assay variability was low. The real-time RT-PCR detected SRBSDV in $87.5 \%$ $100 \%$ of field rice samples compared to $63.6 \%-100 \%$ by conventional RT-PCR. As a whole, the real-time RT-PCR is a valuably alternative method for detecting SRBSDV in rice.
\end{abstract}

Keywords: Southern rice black-streaked dwarf virus; RT-PCR; Viral RNA detection; Quantification; Rice

\section{Introduction}

Southern rice black-streaked dwarf virus (SRBSDV), a latest member of the genus Fijivirus within the family Reoviridae, was simultaneously isolated and identified from the rice in southern of China in 2008 [1,2]. In the following three years (2009-2010), SRBSDV caused the most important rice disease in South of China, there were over ten millions hectare of rice infected, and resulted in massive devastation of rice yield [3].

SRBSDV was most closely related to rice black-streaked dwarf virus (RBSDV); symptoms of infected rice by SRBSDV were similar to RBSDV, such as stunting, dark leaf and small enations on stem and leaf back. Its genome consisted of 10 linear segments of double-stranded RNAs (dsRNA) called S1-S10 in an increasing order of electrophoretic mobility in polyacrylamide gels [1]. The homology of nucleotide sequence of genome segments of SRBSDV was 70.6\%-80.0\% similar to the genome segments of RBSDV. Nevertheless, the SRBSDV was transmitted to rice by white-backed planthoppers, but not by small brown planthopper (RBSDV transmitted vector), and whole genome comparisons and phylogenetic analyses also supported suggestions that SRBSDV represented a new species within the genus Fijivirus, family Reoviridae [4]. So it is exceeding to develop an accurate detecting method for identifying SRBSDV from RBSDV.

Currently, the identification of SRBSDV and its infection is mainly by typical symptoms and RT-PCR [5]. For typical symptoms, it is time consuming, false positive in early diagnosis and severe yield loss by the time it is identified in the infected rice [6]. For RT-PCR, thought it is specific to SRBSDV, false positive still constantly occur, especially in early infected stage in rice because of low quantity of virion in the host [7]. The serological methods are more fast and economical than other methods [8] including in rice and transmitted vector, nevertheless, they are under development. These methods are difficult to precisely quantify SRBSDV, and difficult to rapidly detect the disease for early warning [9]. So it is very important to develop a detecting method for SRBSDV with simple operation, strong specificity, high sensitivity, good reproducibility and quick speed. The real-time RT-PCR is suitable and gradually become an important technique for virus detecting [10-12].

This study aimed to design specific primers and develop an absolute quantification real-time RT-PCR method for detecting SRBSDV, and this method was also applied to detect SRBSDV infection in field samples of rice. For demonstrating the excellent performance of developed real-time RT-PCR, the detection efficiency was also compared with conventional RT-PCR.

\section{Materials and Methods}

\section{Leaf samples of rice}

Leaf samples of rice were collected from heading stage of rice in different districts of Hunan province, China. The leaf samples were gathered in period from 2009 to 2011, there into, some of samples had typical or suspected symptoms of SRBSDV infected, such as stunting, dark leaf and/or small enations on stem and leaf back. And some of healthy rice leaf samples were also collected as control. All leaf samples were quickly frozen by liquid nitrogen, and then stored at $-80^{\circ} \mathrm{C}$.

\section{RNA extraction and cDNA synthesis}

Total RNA was extracted from $100 \mathrm{mg}$ of each leaf sample using the RNA Reagent (consisting of guanidine isothiocyanate and phenol) according to manufacturer's introduction (Anhui U-gene Biotech

*Corresponding author: Yong Liu, Hunan Plant Protection Institute, Hunan Academy of Agricultural Science, Changsha 410125, China, E-mail: haoasliu@163.com

Received June 12, 2013; Accepted July 06, 2013; Published July 12, 2013

Citation: Zhang S, Zhang D, Liu Y, Luo X, Cheng J (2013) Development of a Realtime RT-PCR Method for Rapid Detection and Quantification of Southern Rice Black-streaked Dwarf Virus in Rice. J Plant Pathol Microb 4: 187 doi:10.4172/21577471.1000187

Copyright: @ 2013 Zhang S, et al. This is an open-access article distributed under the terms of the Creative Commons Attribution License, which permits unrestricted use, distribution, and reproduction in any medium, provided the original author and source are credited. 
Citation: Zhang S, Zhang D, Liu Y, Luo X, Cheng J (2013) Development of a Real-time RT-PCR Method for Rapid Detection and Quantification of Southern Rice Black-streaked Dwarf Virus in Rice. J Plant Pathol Microb 4: 187 doi:10.4172/2157-7471.1000187

Page 2 of 4

Co., Ltd, China). The purity was tested by the ratio of $\mathrm{OD}_{260} / \mathrm{OD}_{280}$ absorbance, and RNA concentration was measured at $\mathrm{OD}_{260}$ on a spectrophotometer and calculated (Tu-1901, China). Constant amounts of $1 \mu \mathrm{g}$ of RNA were reversely transcribed to cDNA using Primescript II 1 st Strand cDNA Synthesis Kit with random 6 mers primer according to manufacture's introduction (Takara, Bio Inc, China), cDNA synthesis condition: $25^{\circ} \mathrm{C}$ for $10 \mathrm{~min}$, followed by $42^{\circ} \mathrm{C}$ for $30 \mathrm{~min}, 85^{\circ} \mathrm{C}$ for 5 min, and then stored at $-20^{\circ} \mathrm{C}$.

\section{Primers design}

The nucleotide sequences of segment 9 of SRBSDV and RBSDV were downloaded for the GenBank database, and there was high homology of genome sequence between SRBSDV with RSBDV (74.2 74.9\% identity of segment 9) [2]. Sequence multi-alignment was analyzed by software suite of DNAMAN (Lynnon Biosoft Inc, USA). Primers in the low homology regions segment 9 of SRBSDV were designed in comparison with RBSDV (Figure 1) and by using nucleotide sequence of segment 9 of SRBSDV (EU784843) as target template sequence. Primers, which are specific to SRBSDV, were designed using DNASTAR software (DNASTAR, Inc, USA), and comparison analysis was performed with the sequence in the GenBank nucleotide database by nucleotide BLAST (http://www.ncbi.nlm.nih.nog/).

\section{Recombinant plasmid preparation}

The target fragments of Segment 9 of SRBSDV genome were amplified by the designed primers (Table 2) in $20 \mu$ l volume solution, which consisted of $2 \mu \mathrm{l}$ of the above cDNA, $2.5 \mu \mathrm{l}$ of PCR Buffer, $0.5 \mu \mathrm{l}$ of $\operatorname{dNTP}(10 \mathrm{mmol} / \mathrm{l}), 1.5 \mu \mathrm{l}$ of each primer $(10 \mu \mathrm{mol} / \mathrm{l}), 0.5 \mu \mathrm{l}$ of Taq DNA polymerase (5U/l) (Takara Bio Inc, China) and $13 \mu \mathrm{l}$ of sterilized water. PCR reaction was carried out under the following conditions: $94^{\circ} \mathrm{C}$ for $5 \mathrm{~min}$, followed by 35 cycles at $94^{\circ} \mathrm{C}$ for $30 \mathrm{~s}, 58^{\circ} \mathrm{C}$ for $30 \mathrm{~s}, 70^{\circ} \mathrm{C}$ for $30 \mathrm{~s}$, and a final extension at $70^{\circ} \mathrm{C}$ for $10 \mathrm{~min}$. The PCR products were analyzed by $1.5 \%$ agarose gel electrophoresis.

Ten PCR reactions were conducted for eliminating artifacts with controls (no cDNA). The target PCR products were cut from the agrose gel and recycled by a commercial kit (TIANgel Midi Purification Kit, Tiangen Biotech (Beijing) Co., Ltd, China) according to manufacturer's guidelines.
The plasmid was constructed by inserting the PCR product into the pGEM-T Easy Vector (Promega) according to kit introduction, and then the recombinant was transformed into competent $E$. coli JM109 cells. The cells containing recombinant plasmid were selected by ampicillin $(50 \mathrm{mg} / \mathrm{L})$ and verified by PCR and sequence. The recombinant plasmid DNA was extracted using TIANprep Mini Plasmid Kit (Tiangen Biotech (Beijing), Co., Ltd, China).

\section{Real-time RT-PCR}

The recombinant plasmid was quantified by absorbance at $\mathrm{OD}_{260}$ $\mathrm{nm}$ on a spectrophotometer (Tu-1901, China) and the copy numbers were calculated according to the formula [9]. Copies $/ \mu \mathrm{l}=6 \times 10^{23}$ copies/ mol $\times(\mathrm{C} / \mathrm{MW})$ (C: plasmid concentration [measured by ultraviolet spectrophotometer at $260 \mathrm{~nm}$ ], MW: molecular weight, g/mol). PCR was performed according to the manufacturer's instruction (TransStart ${ }^{\mathrm{TM}}$ Green qPCR SuperMix UDG, Transgen Biotech Co., Ltd, China). The real-time PCR reaction conditions were as follows: $50^{\circ} \mathrm{C}$ for $2 \mathrm{~min}, 95^{\circ} \mathrm{C}$ for $10 \mathrm{~min}, 35 \mathrm{cycles}$ of $95^{\circ} \mathrm{C}$ for $15 \mathrm{~s}, 58^{\circ} \mathrm{C}$ for $30 \mathrm{~s}$, and $72^{\circ} \mathrm{C}$ for $30 \mathrm{~s}$, with a CFX96 Thermal cycler (Bio-Red, USA). The $25 \mu$ real-time PCR mixture contained $1 \mu \mathrm{l} \mathrm{cDNA}$ as template (gradient dilution to proper copies of recombinant plasmid), $0.5 \mu$ l each sense and anti-sense primer (to a final concentration at $0.2 \mu \mathrm{M}$ ), $12.5 \mu \mathrm{l} 2 \times$ Transstart Green qPCR

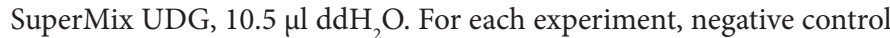
was simultaneously performed by a non-template reaction in triplicate. The specificity of the real-time PCR was confirmed by amplicons size in $1 \%(\mathrm{~W} / \mathrm{V})$ agarose gel.

Threshold cycle $(\mathrm{Ct})$ values were determined at the fluorescence threshold line and arithmetic mean of the triplicate values was calculated. Samples were considered positive only if $\mathrm{Ct}$ value was $<35$ for all replicates [13].

\section{Determination of sensitivity and reproducibility of real-time RT-PCR}

Serially gradient positive plasmids $\left(4.04 \times 10^{2}-4.04 \times 10^{7}\right.$ copies $\left./ \mu l\right)$ were used as templates to determine the sensitivity of the real-time PCR. Intra-assay variability was tested by running a single real-time PCR using four different series in triplicate. Inter-assay variability was determined by running two separate real-time PCR by each dilution

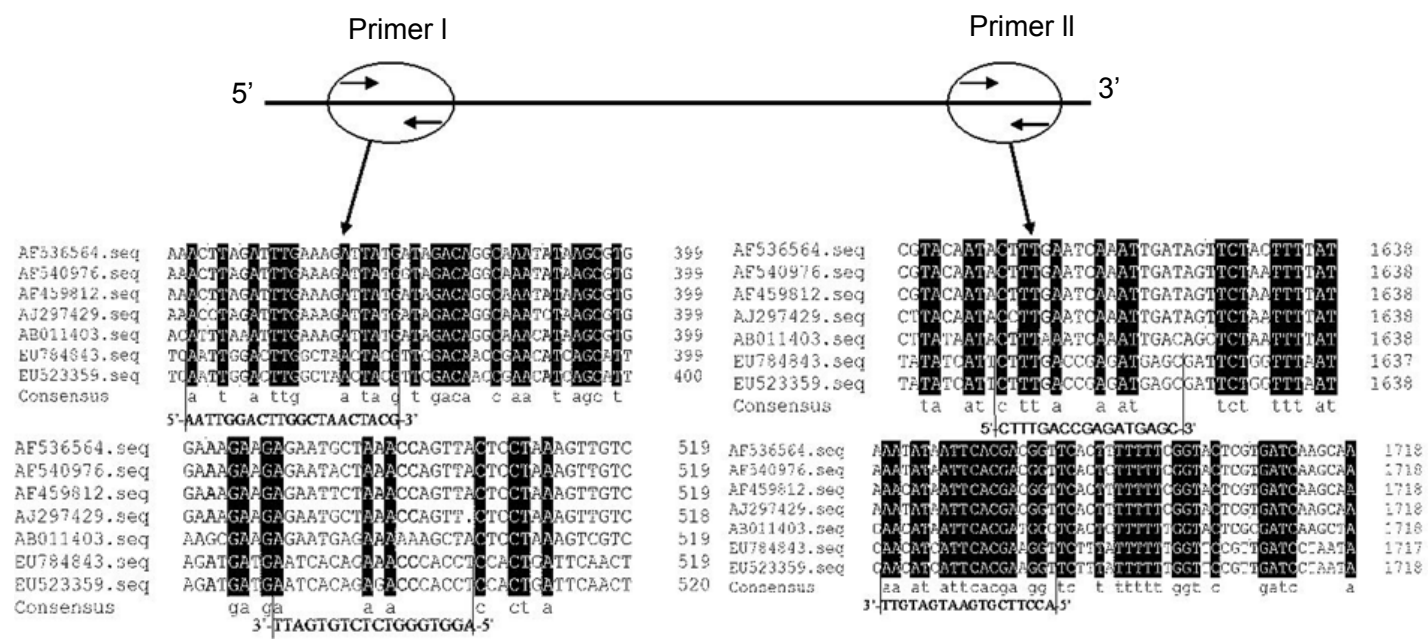

Figure 1: Primers position in the segment 9 of SRBSDV and RBSDV (the reference sequences were selected from GenBank and named by its accession number) 
Citation: Zhang S, Zhang D, Liu Y, Luo X, Cheng J (2013) Development of a Real-time RT-PCR Method for Rapid Detection and Quantification of Southern Rice Black-streaked Dwarf Virus in Rice. J Plant Pathol Microb 4: 187 doi:10.4172/2157-7471.1000187

Page 3 of 4

in triplicate. Statistical analysis was performed using DPS software (version 12.1) [14], and the mean value, Standard Deviation (SD) and Co-efficient Of Variation (CV) were used to evaluate the reproducibility of the real-time PCR.

\section{Conventional RT-PCR of SRBSDV form field rice samples}

The conventional RT-PCR was amplified at 569 bp fragment in Segment 9 of SRBSDV genome by using reported protocol previously [5]. The $50 \mu \mathrm{l}$ mixture contained $2 \mu \mathrm{l}$ RNA extracted from samples, $2 \mu \mathrm{l}$ PrimeScript 1 step Enzyme Mix, $25 \mu \mathrm{l} 2 \times 1$ step buffer, $1 \mu$ each primer $(20 \mu \mathrm{M})$ (Sense: 5'-TTACAYCAAGCACTTTGCGAGG-3', anti-sense: 5'-GGATTACAACAHACAC AMCGAAA-3'), complement dd $\mathrm{H}_{2} \mathrm{O}$ (pre-treated by $0.1 \%$ DEPC) to final volume. The thermal protocol consisted of $50^{\circ} \mathrm{C}$ for $30 \mathrm{~min}, 94^{\circ} \mathrm{C}$ for $3 \mathrm{~min}, 30$ cycles of $94^{\circ} \mathrm{C}$ for 30 $\mathrm{s}, 53^{\circ} \mathrm{C}$ for $30 \mathrm{~s}$, and $72^{\circ} \mathrm{C}$ for $50 \mathrm{~s}$, with a final extension step at $72^{\circ} \mathrm{C}$. RT-PCR products were testified in agarose gel.

\section{Results}

\section{Specificity of real-time RT-PCR}

The specificity of primers of real-time RT-PCR was assessed using nucleotide BLAST (http://ncbi.nlm.nih.gov/), and both primers had no significant homology for other sequences of genus Fujivirus group 2, including the highest homology species of RBSDV. In order to verify the specificity of primers between SRBSDV and RBSDV, conventional RT-PCR was performed in duplicate and electrophoresis in agarose gel (Figure S1). PCR by both specific primers have expected target and distinct specified band from SRBSDV infected rice sample, however no from RBSDV infected rice sample. The band was purified and sequenced, the each sequence was highly homology to SRBSDV using nucleotide BLAST (Figure S2).

The conventional RT-PCR result (Figure S2) also showed that the amplification efficiency by primer S9TF/S9TR was higher than that by primer S9RF/S9RR. The primer S9TF/S9TR was selected for further real-time RT-PCR experiment.

\section{Standard curve and sensitivity of real-time RT-PCR}

Standard curve was generated by 10 -fold serial dilutions of recombinant plasmid $\left(4.04 \times 10^{2}-4.04 \times 10^{7}\right.$ copies/ $\mu$ l) (Figure 2$)$, and a strong linear relationship between the $\mathrm{Ct}$ and the log of the copy number was verified $\left(R^{2} \geq 0.971\right)$. The slope of standard curve was -3.901 , and the efficiency of the reaction calculated by $10^{(-1 / \text { slope })}$ was 1.80 , which was considered acceptable, as it ranged between 1.7-2.3 [15]. The linear equation for the real-time RT-PCR was $y=-3.901 x+6.068$, this method

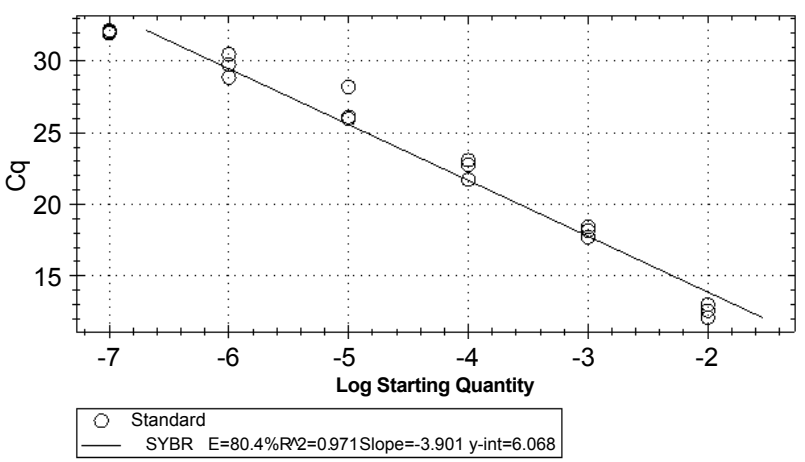

Figure 2: Standard curve generated by real-time RT-PCR x-axis: log starting quantity (series dilution: $10^{2}-10-^{7}$ ); y-axis: Ct value.

\begin{tabular}{|c|c|c|c|c|c|c|}
\hline Sample & \multicolumn{3}{|c|}{ Intra-assay } & \multicolumn{3}{c|}{ Inter-assay } \\
\hline & Mean & S. D. & C. V. (\%) & Mean & S. D. & C. V. (\%) \\
\hline 1 & 12.56 & 0.26 & 3.59 & 11.90 & 0.24 & 3.56 \\
\hline 2 & 18.11 & 0.20 & 1.96 & 17.06 & 0.32 & 3.20 \\
\hline 3 & 22.53 & 0.41 & 3.16 & 21.79 & 0.55 & 4.37 \\
\hline 4 & 29.71 & 0.47 & 2.73 & 29.50 & 0.49 & 2.90 \\
\hline
\end{tabular}

Table 1: Intra- and inter-assay coefficients of variation for the real-time RT-PCR.

\begin{tabular}{|c|c|c|}
\hline Sample No & $\begin{array}{c}\text { Positive rate of real-time } \\
\text { RT-PCR (\%) }\end{array}$ & $\begin{array}{c}\text { Positive rate of conventional } \\
\text { RT-PCR (\%) }\end{array}$ \\
\hline A & $100(n=10)$ & $100(n=10)$ \\
\hline B & $87.5(n=8)$ & $75(n=8)$ \\
\hline C & $90.9(n=11)$ & $63.6(n=11)$ \\
\hline D & $100(n=7)$ & $100(n=7)$ \\
\hline
\end{tabular}

Table 2: Detection of SRBSDV in field samples by real-time RT-PCR and conventional RT-PCR.

was sensitive enough to detect 150 copies of the recombinant plasmid in less than 35 amplification cycles (Figure S3).

\section{Reproducibility of real-time RT-PCR}

The reproducibility of this method was tested using four dilution series of standard plasmids. As shown in table 1, the intra-assay of this method (mean \pm S.D of the CV) was $2.86 \pm 0.40 \%$ (variation range: 1.96 $3.59 \%$ ), and the inter-assay of this method (mean $\pm \mathrm{S}$. D of the CV) was $3.51 \pm 0.37 \%$ (variation range: $2.90-4.37 \%$ ). The results demonstrated excellent reproducibility of this method.

\section{Testing of field samples}

Some of rice leaf samples (with or without symptoms) from each of four districts were tested by the real-time RT-PCR, compared with conventional RT-PCR. The positive rate by the real-time RT-PCR was $87.5 \%-100 \%$, which was higher than conventional RT-PCR (63.6\%$100 \%$ ) (Table 2).

\section{Discussion}

Although, SRBSDV is the latest number of the genus Fijivirus within the family Reoviridae, the infected rice by this virus blossomed in southeast of Asia $[3,16]$. For diagnosis of SRBSDV, typical symptoms and RT-PCR methods need to be detected, and these two methodological approaches are likely to complement rather than replace each other [5]. To best of our knowledge, there are no publications of using the direct molecular quantitative detection of SRBSDV. In this study, the real-time RT-PCR method for quantitative detection of SRBSDV has demonstrated to be specific and sensitive for detection of field rice samples.

The real-time RT-PCR for SRBSDV was designed and used in the field rice samples based on the low homology regions of segment 9 of RBSDV. The results of this study confirmed the specificity of this method for detecting SRBSDV, since the target of amplification was only homology to SRBSDV by the nblast for optimizing the primers (Figure S2). This method was also sensitivity, because of its ability of detection at low density of 150 copies in one reaction. The reproducibility of this method was tested by four dilution series of standard plasmids, and the excellent reproducibility was verified by CV below $4.5 \%$. On the basis of recombinant plasmid standard and not the total RNA standard, the real-time RT-PCR contributed to long-term storage and operation, because plasmid did not easily degraded [9].

Conventional serological methods were efficient and specific for detecting rice viruses, such as RBSDV [17]. At the time of this study, 
Citation: Zhang S, Zhang D, Liu Y, Luo X, Cheng J (2013) Development of a Real-time RT-PCR Method for Rapid Detection and Quantification of Southern Rice Black-streaked Dwarf Virus in Rice. J Plant Pathol Microb 4: 187 doi:10.4172/2157-7471.1000187

a serological detection method (dot-ELISA) was developed for testing rice plants, which was highly reliable, sensitive and specific toward

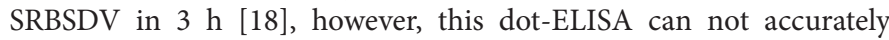
quantify the SRBSDV.

This real-time RT-PCR assay is more precise and sensitive than symptoms and RT-PCR method. Some of field rice samples with suspected symptoms were not infected with SRBSDV, which was confirmed by real-time RT-PCR and conventional RT-PCR. The positive rates $(87.5 \%-100 \%)$ of field rice samples infected with SRBSDV using real-time RT-PCR was higher than those (63.6\%-100\%) of the conventional RT-PCR. The real-time RT-PCR is known of high accuracy for detecting other viruses [19], and this study also demonstrated that real-time RT-PCR was more sensitive as compared to the conventional RT-PCR.

When we prepared the draft of this work, similar quantitative detection of SRBSDV and RBSDV by TaqMan was published [20]. Quantification methods by TaqMan and SYBR Green are reliable for determining gene expression, and although lower sensitive than TaqMan, SYBR Green has its merits of ease in designing the assays and relatively low setup and running costs [21]. So both methods should be rather alternative according to requirements of experiment than substitutive each other.

In summary, the real-time RT-PCR was able to detect SRBSDV, and this might also be important for standardization of quantified detection of SRBSDV. Furthermore, it could potentially be applied for monitoring the virus in the field, predicting virus epidemic development and studying virus-plant-vector interactions [20].

\section{Acknowledgement}

This study was funded by Special Fund for Agro-scientific Research in the Public Interest (no 201003031). We are deeply grateful to Dr Zhou Tong, Institute of Plant Protection of Jiangsu Academy of Agricultural Science for providing infected rice samples by RBSDV.

\section{References}

1. Zhang HM, Yang J, Chen JP, Adams MJ (2008) A black-streaked dwarf disease on rice in China is caused by a novel fijivirus. Arch Virol 153: 1893-1898.

2. Zhou GH, Wen JJ, Cai DJ, Li P, Xu DL, et al. (2008) Southern rice blackstreaked dwarf virus: a new proposed Fijivirus species in the family Reoviridea. Chin Sci Bull 53: 3677-3685.

3. Zhou G H, Zhang SG, Zou SF, Xu ZW, Zhou ZQ (2010) Occurrence and damage analysis of a new rice dwarf disease caused by southern rice blackstreaked dwarf virus. Plant Protection 36: 144-146.

4. Wang Q, Yang J, Zhou GH, Zhang HM, Chen JP, et al. (2010) The complete genome sequence of two isolates of southern rice black-streaked dwarf virus, a new member of the genus Fijivirus. J Phytopathol 158: 733-737.

5. Ji YH, Gao RZ, Zhang Y, Cheng ZB, Zhou T, et al. (2011) A simplified method for quick detection of rice black streaked dwarf virus and southern rice black streaked dwarf virus. Chin J Rice Sci 25: 91-94.

6. Cuong HV, Hai NV, Man VT, Matsumoto M. (2009) Rice dwarf disease in North Vietnam in 2009 is caused by southern rice black-streaked dwarf virus (SRBSDV). Bull Inst Trop Agr Kyushu Univ 32: 85-92.

7. Le DT, Netsu O, Uehara-Ichiki T, Shimizu T, Choi IR, et al. (2010) Molecular detection of nine rice viruses by a reverse-transcription loop-mediated isothermal amplification assay. J Virol Methods 170: 90-93.

8. Wang ZH, Fang SG, Zhang ZY, Han CG, Li DW, et al. (2006) Development of an ID-ELISA for the detection of Rice black-streaked dwarf virus in plants. $J$ Virol Methods 134: 61-65.

9. Lv J, Wei B, Chai T, Xia X, Miao Z, et al. (2011) Development of a real-time RT-PCR method for rapid detection of $\mathrm{H} 9$ avian influenza virus in the air. Arch Virol 156: 1795-1801.

10. Li PQ, Zhang J, Muller CP, Chen JX, Yang ZF, et al. (2008) Development of a multiplex real-time polymerase chain reaction for the detection of influenza virus type A including H5 and H9 subtypes. Diagn Microbiol Infect Dis 61: 192 197

11. Payungporn S, Chutinimitkul S, Chaisingh A, Damrongwantanapokin S, Buranathai C, et al. (2006) Single step multiplex real-time RT-PCR for H5N1 influenza A virus detection. J Virol Methods 131: 143-147.

12. Wang F, Qin GZ, Sui ZH, Wang ZH, Wang ZY, et al. (2006a) Improved method for assaying maize plant resistance to maize rough dwarf disease by artificial inoculation and real-time RT-PCR. Eur J Plant Pathol 116: 289-300.

13. Hummel KB, Lowe L, Bellini WJ, Rota PA (2006) Development of quantitative gene-specific real-time RT-PCR assays for the detection of measles virus in clinical specimens. J Virol Methods 132: 166-173.

14. Tang QY, Feng MG (2007) DPSTM data processing system-Experimental design, statistical analysis and data mining. Science press, Beijing, pp 112-126.

15. Sidoti F, Rizzo F, Costa C, Astegiano S, Curtoni A, et al. (2010) Development of real time RT-PCR assays for detection of type A influenza virus and for subtyping of avian $\mathrm{H} 5$ and $\mathrm{H} 7$ hemagglutinin subtypes. Mol Biotechnol 44: 4150 .

16. Hoang AT, Zhang HM, Yang J, Chen JP, Eugénie H, et al. (2011) Identification, characterization, and distribution of southern rice black-streaked dwarf virus in Vietnam. Plant Dis 95: 1063-1069.

17. Hortmani M, Izadpanah K. (2006) Partial physicochemical characterization and serological detection of Iranian isolate of maize rough dwarf virus. Iran J Plant Pathol 42: 563-575.

18. Wang Z, Yu D, Li X, Zeng M, Chen Z, et al. (2012) The development and application of a Dot-ELISA assay for diagnosis of southern rice black-streaked dwarf disease in the field. Viruses 4: 167-183.

19. Modibedi LG. (2008) Development of a single real-time RT-PCR method for the group-specific identification of African horsesickness virus and bluetongue virus, MSc dissertation, University of Pretoria, Pretoria.

20. Zhang P, Mar TT, Liu W, Li L, Wang X (2013) Simultaneous detection and differentiation of Rice black streaked dwarf virus (RBSDV) and Southern rice black streaked dwarf virus (SRBSDV) by duplex real time RT-PCR. Virol J 10 : 24.

21. Cao HP, Shockey JM (2012) Comparison of TaqMan and SYBR qPCR methods for quantitative gene expression in tung tree tissues. J Agric Food Chem 60 12296-12303.

22. Gadiou S, Ripl J, Jaňourová B, Jarošová J, Kundu JK (2012) Real-time PCR assay for the discrimination and quantification of wheat and barley strains of Wheat dwarf virus. Virus Genes 44: 349-355. 